\title{
Convergence between competition and data protection law: A South African Perspective
}

Pieter Koornhof ${ }^{*}$

Tana Pistorius ${ }^{* *}$

\section{Introduction}

The traditional goal of competition law is to regulate markets to ensure that the conditions for free and/or fair competition are promoted. From a traditional economic point of view, the purpose of competition law and regulation is to place constraints on certain forms of commercial conduct in order to promote competition in markets. Promoting competition is seen as essential for attaining economic efficiencies, leading to innovation and growth in markets. ${ }^{1}$ In turn, the stated purposes of the South African Competition $\mathrm{Act}^{2}$ include, inter alia, promoting the efficiency, adaptability and development of the economy, ${ }^{3}$ providing consumers with competitive prices and product choices, ${ }^{4}$ advancing the social and economic welfare of South Africans, ${ }^{5}$ and ensuring that small and medium-sized enterprises have an equitable opportunity to participate in the economy. ${ }^{6}$ It would therefore appear from these goals that South African competition law has a distinctly socio-economic emphasis. Alongside with ensuring free and fair competition, the promotion of consumer welfare and welfare in general is also of paramount importance. ${ }^{7}$ These objectives therefore accord with those in most other notable competition law jurisdictions.

Whereas consumer protection is neither a direct objective of competition law nor data protection law in South Africa, arguably both bodies of law seek to promote

\footnotetext{
* BA LLB LLM (Stell), Attorney of the High Court of South Africa, Lecturer: Aston Law School, Birmingham. Email: p.koornhof@aston.ac.uk

** BA (UP) LLB (Unisa) LLM LLD (UP), Attorney and Notary of the High Court of South Africa, South African Research Chair in Law, Society and Technology, Professor of Law, University of South Africa. Email: pistot@unisa.ac.za

${ }^{1}$ R Pindyck \& D Rubinfeld, Microeconomics (Fifth Edition, Prentice Hall, 2000) at 359-360 and again at 364

${ }^{2}$ Act 89 of 1998, as amended (hereafter "the Competition Act")

${ }^{3}$ Section 2(a) of the Competition Act

${ }^{4}$ Section 2(b) of the Competition Act

${ }^{5}$ Section 2(c) of the Competition Act

${ }^{6}$ Section 2(e) of the Competition Act

${ }^{7} \mathrm{M}$ Brassey et al, Competition Law (Juta, 2002) at 2. See also Minister of Economic Development v Competition Tribunal 110/CAC/Jun11 (09/03/2012) at paragraph 98
} 
the interests of consumers. With regard to competition law, this is done by promoting consumer welfare and fair competition. In terms of data protection law this is evidenced by, inter alia, provisions guarding against the misuse of personal information and regulating direct marketing. As such, it is submitted that the regulation of competition and data protection in South Africa converge on the topic of consumer protection. In order to show the extent of convergence, and specifically where any tangents and tensions may lie, a brief overview of competition law and enforcement as well as data protection will be given. Specific examples of anti-competitive conduct relating to the processing of personal information will also be discussed. It is clear that the lens through which the Competition Commission views such conduct differs from that of the Information Regulator ${ }^{8}$ and that the diverging approaches lead to disparate results. This forms the backdrop to a discussion on the desirability and scope of possible future cooperation between authorities in South African regulating competition and data protection.

\section{Competition Regulation in South Africa}

Unless a specific form of activity has been excluded from the Act, or the regulation of competition matters is provided for in terms of another piece of legislation, all matters of competition law must be dealt with in terms of the South African Competition Act. Section 3(1) of the Competition Act provides that the Act 'applies to all economic activity within, or having an effect within, the Republic' with the exception of some activities. ${ }^{9}$ Both the phrases 'economic activity' and 'having an effect within' have been broadly interpreted by courts in South Africa. ${ }^{10}$ As such, South African Competition Law has quite a broad jurisdictional remit. While it is not unusual for competition laws

\footnotetext{
8 Hereafter "Regulator".

${ }^{9}$ See Section 3(1)(a) to (e) of the Competition Act. These, for the most part, relate to matters of labour law, or related non-commercial socio-economic aspects.

${ }^{10}$ See Competition Commission v American Natural Soda Ash Corporation I/ 49/CR/Apr00 and 87/CR/Sep00; American Soda Ash Corporation and Another v Competition Commission of South Africa and Others (12/CAC/DEC01) [2002] ZACAC 5 and American Natural Soda Ash Corporation and Another v Competition Commission of South Africa (554/2003) [2005] ZASCA 42
} 
in a variety of countries to have a similar potential reach, their extraterritorial application is often reined in through legislation or principles derived from case law. ${ }^{11}$

Broadly speaking, the duties of competition authorities can be divided into three categories. The first duty relates to regulation of anti-competitive conduct by a firm or groups of firms, ${ }^{12}$ the second the evaluation of mergers between firms, ${ }^{13}$ and the final is the conducting of market inquiries. ${ }^{14}$ It is submitted that competition and data privacy law most likely intersects in relation to both the regulation of anti-competitive conduct and market inquiries.

\section{$\underline{\text { Regulation of anti-competitive conduct }}$}

With regard to the regulation of anti-competitive conduct, the Competition Act regulates horizontal restrictive practices, vertical restrictive practices, and abuses of a dominant position. Horizontal restrictive practices refer to practices and agreements between supposedly competing firms who then collude in order to prevent or lessen competition in a market for particular goods and services. Acts which are specifically prohibited include price fixing, ${ }^{15}$ the division and allocation of markets, ${ }^{16}$ and collusive tendering, ${ }^{17}$ although any conduct that has a nett anti-competitive effect can be regulated. ${ }^{18}$ Vertical restrictive practices commonly include agreements between suppliers and distributors purporting to regulate exclusive distribution, exclusive dealing or attempts to tie unrelated products together. The only act specifically prohibited is any practice seeking to restrict competition on minimum resale prices of products. ${ }^{19}$ Abuse of dominance refers to the conduct of single firm with a dominant market position which is sufficiently powerful that they are able to distort competition on their own. ${ }^{20}$ The South African Competition Act regulates price discrimination, ${ }^{21}$

\footnotetext{
${ }^{11}$ P Sutherland \& K Kemp, Competition Law of South Africa (LexisNexis Butterworths, Service Issue 21, 2017) at 4-26 to 4-28

${ }^{12}$ Chapter 2 (Sections 4 to 10 ) of the Competition Act.

${ }^{13}$ Chapter 3 (Sections 11 to 18 ) of the Competition Act

${ }^{14}$ Chapter 4A (Section 43A to 43C) of the Competition Act.

${ }^{15}$ Section 4(1)(b)(i) of the Competition Act

${ }^{16}$ Section 4(1)(b)(ii) of the Competition Act

${ }^{17}$ Section 4(1)(b)(iii) of the Competition Act

${ }^{18}$ Section 4(1)(a) of the Competition Act

${ }^{19}$ Section 5(2) of the Competition Act

${ }^{20}$ Sutherland \& Kemp (2017) at 7-5

${ }^{21}$ Section 9 of the Competition Act
} 
excessive pricing, ${ }^{22}$ the refusal of access to essential facilities ${ }^{23}$ and a variety of exclusionary acts (both specifically and in general). ${ }^{24}$

In order to regulate the above forms of conduct effectively, Chapter 5, Part B of the Competition Act provides the Competition Commission with a broad range of investigatory powers, including the authority to enter and search premises with or without a warrant. Section 58 further provides for remedies that can be imposed on firms infringing the act, including interdicts, ${ }^{25}$ orders of divestiture, ${ }^{26}$ declaratory orders that conduct has infringed the act, ${ }^{27}$ and the imposition of administrative penalties. ${ }^{28}$ Whereas these powers and remedies may at times be seen as excessive, it is not uncommon amongst competition authorities world-wide, though it has led to some debate as to the nature of competition law enforcement and whether it should be seen as criminal or civil in nature. ${ }^{29}$

\section{Market Inquiries}

The Competition Act allows for the Commission to conduct a formal inquiry into a particular market in order to assess the general state of competition therein. ${ }^{30}$ This may be done on its own initiative, or in response to a request of the Minister of Trade and Industry, provided that there is reason to believe that features of the market may be affecting competition therein, or that the inquiry is necessary to achieve the purposes of the act. ${ }^{31}$ Prior to an inquiry, a notice setting out its scope and expected time of completion must be published, ${ }^{32}$ and a report must be completed and published subsequent to the inquiry. ${ }^{33}$ The report may include recommendations for new or

\footnotetext{
22 Section 8(a) of the Competition Act

${ }^{23}$ Section 8(b) of the Competition Act

${ }^{24}$ Sections 8(c) and 8(d) of the Competition Act

${ }^{25}$ Section 58(1)(a)(i) of the Competition Act

${ }^{26}$ Section 58(1)(a(iv) of the Competition Act

27 Section 58(1)(a)(v) of the Competition Act

${ }^{28}$ Section 58(1)(a)(iii) of the Competition Act. The nature and amount of administrative penalties are further determined by Section 59 of the Act.

${ }^{29}$ See D Prins \& P Koornhof "Assessing the nature of competition law enforcement in South Africa” Law, Democracy and Development, Vol 18 (2014) 136

${ }^{30}$ Section 43A of the Competition Act

${ }^{31}$ Section $43 B(1)$ of the Competition Act

32 Section 43B(2) and (4) of the Competition Act

${ }^{33}$ Section 43B(6) of the Competition Act
} 
amended policy, legislation or regulation, as well as recommendations to other regulatory authorities in respect of competition matters. ${ }^{34}$ The inquiry may also lead to further steps being taken, including the initiation and/or referral of complaints against firms found to have engaged in anticompetitive behaviour. ${ }^{35}$ The conditions required for the initiation of an inquiry are quite broad. Accordingly, inquiries could be conducted in newer markets under the auspices of achieving the purposes of the act and the Commission could probably justify such an investigation into markets for the processing of personal information with relative ease.

\section{Data protection in South Africa}

South Africa has adopted a nuanced approach to data protection. Privacy is protected in terms of section 14 of the Constitution of the Republic of South Africa. ${ }^{36}$ The preamble to the Protection of Personal Information Act ${ }^{37}$ notes that unnecessary impediments to the free flow of information should be addressed consonant with the constitutional values of democracy and openness, and the need for economic and social progress within the framework of the information society.

The express imperatives for digital inclusion and the need to grow the digital economy are limited. Instead, the purpose of POPIA is to give effect to the constitutional right to privacy. This is sought to be accomplished by safeguarding personal information when processed by a responsible party, subject to justifiable limitations that are aimed at

“(i) balancing the right to privacy against other rights, particularly the right of access to information; ${ }^{38}$ and

(ii) protecting important interests, including the free flow of information within the Republic and across international borders". 39

\footnotetext{
${ }^{34}$ Section $43 C(1)$ of the Competition Act

${ }^{35}$ Section $43 C(3)$ of the Competition Act

${ }^{36}$ Constitution of the Republic of South Africa, 1996

${ }^{37}$ Act 4 of 2013 (hereafter "POPIA").

${ }^{38}$ See Promotion of Access to Information Act 2 of 2000 (hereafter simply 'PAIA').

${ }^{39}$ Section 2(a) of POPIA.
} 


\section{The scope and interpretation of POPIA}

POPIA has a wide scope of application. It applies to the personal information of identifiable, living natural persons and identifiable existing juristic persons. ${ }^{40} \mathrm{Natural}$ persons and companies are data subjects. The definition of a responsible party includes a public or private body. ${ }^{41}$ POPIA thus regulates the processing of personal information of natural persons and companies or other incorporates. It also applies to the processing of personal information by the administration in the national, provincial or local governmental spheres. POPIA also applies to the processing of personal information by other regulators.

POPIA regulates the manner in which personal information may be processed by establishing conditions that prescribe the minimum threshold requirements for the lawful processing of personal information..$^{42}$ It provides rights and remedies to data subjects if their personal information is processed unlawfully ${ }^{43}$ and establishes voluntary and compulsory measures to promote respect for and the enforcement of the rights protected by POPIA. ${ }^{44}$ POPIA applies to the processing of personal information where the responsible party is domiciled in the Republic, or makes use of automated or non-automated means in the Republic, unless those means are used only to forward personal information through the Republic. ${ }^{45}$

POPIA establishes the principle that whatever legislative provision provides the most protection to data subjects will prevail. Where any provision of any other legislation that regulates the processing of personal information is materially inconsistent with an object or a specific provision POPIA, POPIA will apply to the exclusion of that provision. ${ }^{46}$ However, if any other legislation provides for conditions for the lawful processing of personal information that are more extensive than those set out in Chapter 3 of POPIA, then the extensive conditions provided for in that legislation prevail. ${ }^{47}$

\footnotetext{
${ }^{40}$ See the definition of "personal information" and "person" in section 1 of POPIA.

${ }^{41}$ See the definition of "responsible party"; "private person" and "public person" in section 1 of POPIA..

${ }^{42}$ Section 2(b) of POPIA.

${ }^{43}$ Section 2(c) of POPIA.

${ }^{44}$ Section 2(d) of POPIA.

${ }^{45}$ Section 3(1)(b) of POPIA.

${ }^{46}$ Section 3(2)(a) of POPIA.

${ }^{47}$ Section 3(2)(b) of POPIA
} 
POPIA must be interpreted in a manner that gives effect to its purpose set out in section $2 .{ }^{48}$ Furthermore, POPIA should be interpreted to facilitate, rather than inhibit, the exercising or performing of powers, duties and functions of public and private bodies that relate to the processing of personal information.

\section{The Information Regulator}

The Regulator is an independent body established in terms of section 39 of POPIA. It is subject only to the law and the Constitution and it is accountable to the National Assembly. The Regulator has a dual constitutional mandate framed by the rights of privacy ${ }^{49}$ and access to information. ${ }^{50}$ Accordingly, it is empowered to monitor and enforce compliance by public and private bodies in line with the provisions of PAIA and POPIA.

POPIA lists certain activities which are considered to be an interference with the protection of personal information of a data subject. The list of activities is relatively expansive, and accordingly only those interferences that are relevant to the regulation of anti-competitive conduct are outlined below. An aggrieved person may lodge a complaint with the Regulator in connection with a breach of the conditions for the lawful processing of personal information. ${ }^{51}$

It should be noted that POPIA is not yet fully in operation and only certain sections of POPIA have been proclaimed. The remaining sections of POPIA will commence once the office of the Regulator is fully operational. Notwithstanding this, the comments on the application of POPIA in relation to anticompetitive uses for and of personal information are not affected by this fact.

\footnotetext{
${ }^{48}$ See section 3(3) of POPIA.

${ }^{49}$ Constitution of the Republic of South Africa, Section 14

${ }^{50}$ Constitution of the Republic of South Africa, Section 32

${ }^{51}$ Chapter 3 of POPIA.
} 
$\underline{\text { Conditions for the lawful processing of personal information }}$

POPIA prescribes eight conditions for the lawful processing of personal information. These conditions are cumulative, apply horizontally, and broadly accord with the principles found in the General Data Protection Regulation. ${ }^{52}$ Only some of the conditions that may be relevant to the anti-competitive uses for and of personal information are discussed here.

The processing limitation provides that data subjects' consent is required for the processing of their personal information. Consent requires a voluntary, specific, and informed expression of will in terms of which permission is given for the processing of personal information. POPIA also provides that personal information must be collected directly from data subjects except where compliance would prejudice a lawful purpose of the collection or is not reasonably practicable in the circumstances of the particular case. ${ }^{53}$ The purpose specification requires personal information to be collected for a specific and lawful purpose related to a function or activity of the responsible party. ${ }^{54}$ The further processing limitation provides that any further processing must be compatible with the original purpose for which the personal information was collected. ${ }^{55}$ Data subjects must be notified of the collection of their personal information in accordance with the openness condition. The condition that relates to information quality requires a responsible party to take reasonably practicable steps to ensure that the personal information it is processing is complete, accurate, not misleading and updated where necessary. Lastly, section 70 of POPIA prohibits automated decision making which is based on the automated processing of a data subject's personal information through which, for example, a person's personal preferences or conduct are outlined.

\section{Anti-competitive uses for and of personal information}

Recent data breaches and investigations (such as those revolving around Cambridge Analytica, for example) have made it abundantly clear that the abusive use of data can

\footnotetext{
52 General Data Protection Regulation (EU) 2016/679

53 Section $12(2)(\mathrm{e})-(\mathrm{f})$ of POPIA.

54 Section 12 of POPIA.

${ }^{55}$ Section 15 of POPIA.
} 
have massive potential implications for society, and that there is a lack of understanding surrounding the practice and impact of data analytics. ${ }^{56}$ While most of these have shown how data misuse could potentially affect a political landscape, personal information can be used (or is being used) in a similar manner by commercial operators through automated decision making.

Notable examples of the anti-competitive uses for and of personal information are broadly discussed below. It is foreseen that an operator could share data between itself and third parties which also happen to be its competitors (or affiliated to its competitors), and such information could then be used to facilitate a variety of collusive practices. It is also not uncommon for the privacy policies of companies to allow for processing of personal information for 'business purposes,' a sufficiently broad term which could include the sharing of data. ${ }^{57}$ When this is done, it would be particularly difficult to show that customers within a market are being allocated between competitors on the basis of a particular information profile.

The sharing of personal information will not necessarily contravene the Competition Act. Firstly, information sharing between competitors would be allowed under several circumstances, for example when establishing joint ventures or to coordinate efforts to allow for greater competition in export markets. ${ }^{58}$ Secondly, analysis of its potential anti-competitive effects can often be quite complex ${ }^{59}$ and the sharing of personal information may not directly be linked to the anti-competitive outcomes. However, from a POPIA point of view the sharing of personal information of data subjects between third parties may breach a number of the conditions for the lawful processing of personal information, including the processing limitation (consent), the purpose specification, the further processing limitation and openness.

\footnotetext{
${ }^{56}$ R Cellan-Jones, "Tech Tent: Your data in political hands?" (BBC News, 13 July 2018) < https://bbc.in/2uDgKmR> last accessed 19 July 2018; Information Commissioner's Office, "Investigation into the use of data analytics in political campaigns: Investigation Update" (10 July 2018) available at https://ico.org.uk/media/action-weve-taken/2259371/investigation-into-data-analytics-for-political-purposesupdate.pdf (Last accessed 20 July 2018)

57 See for instance the provisions of Coca-Cola's Privacy Policy, available at https://www.cocacolacompany.com/our-company/privacy-policy (Last accessed 21 August 2018)

58 In terms of the latter, the Western Cape Citrus Producers Forum has been granted several conditional exemptions from the Act to allow for this. See Notice in Terms of Section 10(7) of the Act: The Western Cape Citrus Producers Forum Granted Conditional Exemption, Government Notice 65/2018 (2 February 2018)

${ }^{59}$ Sutherland \& Kemp (2017) at 5-91 to 5-93
} 
Such conduct may also amount to automated decision prohibited in terms of section 71 of POPIA.

Aside from the facilitation of collusive practices, information could similarly be used to engage in targeted "misinformation campaigns" to dissuade consumers from dealing with particular businesses. In the hands of a dominant firm, data analytics could easily be used to facilitate price discrimination, not to mention the charging of excessive prices or predatory pricing strategies. A dominant firm could also possibly use such tactics as a means of inducing customers not to deal with potential competitors in a similar manner to how colluding firms could use targeted misinformation. From a competition law point of view, there is a grey area between what would be considered clever marketing strategies and what constitutes conduct amounting to the inducement of customers not to deal with a particular company. ${ }^{60}$ However, if viewed from a data protection point of view the Regulator will be able to play a meaningful role in curbing such collusive practices. The use of targeted misinformation will likely involve the processing of personal information of or in relation to competing firms. In such instances the processing will involve a breach of the conditions for the lawful processing of personal information including the processing limitation (consent), the purpose specification, the further processing limitation; openness and information quality. The fact that the personal information of juristic persons is protected widens the mandate of the Regulator considerably. As a result, the compliance obligations of all responsible parties may have a sobering impact on information-rich collusive practices in South Africa.

There is currently some debate as to whether data platforms in the hands of dominant firms may be seen as an essential facility which actual or potential competitors should be granted access to. ${ }^{61}$ Whereas this is a complex, nuanced issue in other jurisdictions, it is submitted that the definition of what constitutes an "essential facility" in the South African context requires that the infrastructure or resource cannot

\footnotetext{
${ }^{60}$ In this regard, see the judgment in Competition Commission and Another $v$ British American Tobacco South Africa (Pty) Ltd (05/CR/Feb05) [2009] ZACT 46 at paragraphs 41 to 58.

${ }^{61}$ See G Colangelo \& M Maggiolino ‘Big Data as misleading facilities' European Competition Journal Vol 14, Issue 2-3 (2017) pp 249-281; K Stout 'Senator Warner's retrogressive proposals could lead to arbitrary and capricious interventions that would harm entrepreneurs and consumers' Truth on the Market (10 August 2018) available at https://truthonthemarket.com/2018/08/10/senator-warners-retrogressive-proposals-could-leadto-arbitrary-and-capricious-interventions-that-would-harm-entrepreneurs-and-consumers/ (Last accessed 21 August 2018)
} 
reasonably be duplicated, and without access a firm would not reasonably be able to provide goods or services. ${ }^{62}$ Merely frustrating competitive efforts or arguing that there are high costs involved in duplicating the resources or in coming up with an alternative solution will not suffice. ${ }^{63}$ Whereas it is possible that this issue might be raised in South Africa at some point in the future, it is submitted that it is unlikely to be a problem in practice given the current context. If viewed from a data protection perspective, the conditions for the lawful processing of personal information may form a bar against access by actual or potential competitors. Such conditions include the processing limitation (consent and the collection of personal information directly from the data subject). Access may also breach other conditions for the lawful processing of personal information, such as the purpose specification, the further processing limitation and openness.

As noted above, the Competition Act seeks to promote the development of the economy and consumer choices as far as competitive prices and product choices are concerned. POPIA, in turn, seeks to protect the rights of data subjects (and in this case competitors) as regards the processing of their personal information. Given this, it is submitted that there are clear overlaps between the objectives of competition law and that of data protection law. The Regulator and the Competition Commission could address these issues through greater cooperation. Accordingly, the extent to which this is possible must be assessed.

\section{Scope for cooperation between the Competition Commission and Information}

\section{Requlator?}

If the Regulator considers that a complaint relates (either wholly or partially) to a matter that is regulated in terms of another law, it must first consult with the relevant regulatory authority in order to determine if the complaint should be dealt with in terms of POPIA. ${ }^{64}$ If it is subsequently determined that the complaint should be dealt with by another body, the Regulator must refer the matter. ${ }^{65}$ As such, any matters where

\footnotetext{
62 Section 1 of the Competition Act

${ }^{63}$ Also see the judgment in the ECJ Oscar Bronner case (Case C-7/97) which has been used by South African competition courts when interpreting the definition of an essential facility.

${ }^{64}$ Section 78(1) of POPIA

${ }^{65}$ POPIA Section 78(2) of POPIA
} 
competition law considerations arise should be brought under the attention of the Competition Commission and would subsequently likely be dealt with by it.

While it may be argued that the Competition Commission is likely to be the best body to deal with matters of competition law, they do not necessarily possess adequate knowledge or understanding of the processes and principles of data protection either in general or how it specifically applies in the South African context. One of the express functions of the Competition Commission is to negotiate agreements with any regulatory authority to coordinate and harmonise the exercise of jurisdiction over competition matters within a relevant industry or sector, and to ensure the consistent application of the principles of the Competition Act. ${ }^{66}$ If there is concurrent jurisdiction between two authorities, a cooperation agreement must be entered into. ${ }^{67}$ Additionally, any organ of state must assist the Commission in the carrying out of its duties or powers. ${ }^{68}$

Whereas there is clearly no concurrent jurisdiction between the Competition Commission and the Regulator, there exists a duty on the Regulator to co-operate with the Commission regarding the referral of complaints. It is submitted that a cooperation agreement between the two bodies would be advisable as the unlawful processing of personal information can have anti-competitive effects apart from the interference with the protection of personal information of data subjects. It is likely that a great number of issues will arise in future falling within the legislative mandate of both the Regulator and the Competition Commission. Such agreements are also not uncommon, given that several already exist between the Commission and other organs of state where there is no concurrent jurisdiction but where cooperation is seen as mutually beneficial. ${ }^{69}$

\footnotetext{
${ }^{66}$ Section 21(1)(h) of the Competition Act

67 Section 82(1) of the Competition Act read along with Section 3(1A)

68 Section 20(3) of the Competition Act

${ }^{69}$ Examples of agreements currently in place where there is no concurrent jurisdiction include ones with the International Trade and Administration Commission of South Africa, the South African Bureau of Standards, and various ministerial departments.
} 


\section{Concluding Remarks}

On 1 December 2017, a draft competition amendment bill was published for public commentary. Shortly thereafter, on 11 July 2018, the Competition Amendment Bill70 was tabled in the South African National Assembly. Among other things, the Bill proposes to provide competition authorities with broader powers in relation to market inquiries and it expands the list of expressly prohibited conduct amounting to the abuse of dominance. Most pertinently, the Bill mandates that the Competition Commission must publish guidelines in relation to various forms of anti-competitive conduct ${ }^{71}$ and clarifies the process of consultation in relation to such guidelines. ${ }^{72}$ Furthermore, the Bill expands the ambit of issues that other regulatory authorities must cooperate with the Competition Commission on, including express references to market inquires. ${ }^{73}$ Whereas the Bill has been criticised for being harsh to business at times, ${ }^{74}$ it shows an attempt to align competition law and processes with related public policies. Accordingly, for the purposes of this contribution, it does serve to bolster the argument that there is sound rationale for the Competition Commission and Regulator to enter into a cooperation agreement in the not too distant future.

It is submitted that the substantive content and extent of any cooperation agreement between the Competition Commission and the Regulator should not seek to create an unnecessary additional layer of competition regulation for responsible parties (data processors). For instance, competition authorities could be consulted by the Regulator when developing codes of conduct to ensure that anti-competitive effects are not unduly or inadvertently facilitated. However, the mere fact that data processing and the transfer of personal information may have an effect on competition does not mean that the Commission should investigate or regulate the industry more fastidiously than it does any other industry or product. The focus should not be on the content of the service or the market itself - except, naturally, when a market inquiry is being conducted. Rather, the focus must be on the conduct of individual responsible

\footnotetext{
${ }^{70}$ Competition Amendment Bill, B23-2018, hereafter simply 'the Bill.'

${ }^{71}$ Clauses 3 to 5 of the Bill

${ }^{72}$ Clause 38 of the Bill

${ }^{73}$ Clause 40 of the Bill

74 See R Lake 'Competition Amendment Bill 2018 aims to protect market participation of non-dominant firms' Regulation Tomorrow (16 August 2018) available at https://www.regulationtomorrow.com/africa/competition-amendment-bill-2018-aims-to-protect-marketparticipation-of-non-dominant-firms/ (Last accessed 21 August 2018)
} 
parties and an analysis of its anti-competitive effects accordingly. Adopting such an approach would be comparable to the position that has evolved over time in relation to the convergence between competition and intellectual property law. ${ }^{75}$

75 In general, see P Sutherland \& P Koornhof "Interface between competition and intellectual property law" in A Van der Merwe et al, Law of Intellectual Property in South Africa ( $2^{\text {nd }}$ Edition, LexisNexis, 2016) at 529-544. 